\title{
Molecular approaches to improved pig fertility*
}

\author{
M. F. Rothschild, L. A. Messer and A. Vincent \\ 225 Kildee Hall, Department of Animal Science, lown State University, Ames, IA 50011-3150, USA
}

\begin{abstract}
Geneticists have made limited progress in improving reproductive traits in pigs through traditional selection and crossbreeding systems. Recent advances in molecular genetics and the human genome project have allowed progress in gene identification and gene mapping in pigs. The pig genetic linkage map now has over 1700 genetic markers, and about 200 of these are genes. Furthermore, comparative genomic maps are improving and are becoming useful tools. Molecular approaches such as candidate gene identification and genomic scans permit new genes and chromosomal regions to be discovered which may influence reproduction. One significant finding is that the oestrogen receptor locus (ESR) is associated with increased litter size. Differences between female Chinese pig ESR BB and AA homozygotes have averaged 2.3 pigs born alive for first parity, and in commercial Large White crosses the differences are about 0.9 pigs per litter. Additional new genes have been discovered which may significantly affect litter size. Initial genome scans have revealed that there may be a gene or genes influencing ovulation rate and litter size on chromosome 8. Approaches such as positional comparative candidate gene analysis and eventually positional cloning will probably identify the genes controlling reproduction in pigs.
\end{abstract}

\section{Introduction}

By their very nature, reproductive processes must be under a high level of genetic control for the maintenance of the species. Despite this level of control, there is considerable variability in heritable traits such as total number of pigs born. Genetic improvement of reproductive traits has traditionally been restricted to use of quantitative genetic methods including selection, inbreeding and crossbreeding but gains have been limited using these methods (Rothschild, 1996).

Molecular genomic analysis has revolutionized how geneticists examine the genetic differences within domesticated pigs. In the past few years, efforts have been directed toward the development of a genomic map consisting of anonymous genetic markers. This initial advance is now being followed by the discovery and mapping of genes of biological and economic interest. Present and future genetic improvements will result from the growing understanding of the function and structure of the individual genes and gene families that are responsible for the reproductive traits in livestock species. In this review the recent discoveries of individual genes involved in reproduction are discussed and molecular genetic approaches that have and will be useful in the discovery of new genes controlling increased fertility in pigs are described.

\section{Gene Mapping Overview}

Genome mapping in livestock is an on-going process that has far exceeded early expectations. Our progress has in part been due to the success of the well funded US Human Genome Project (Collins and Galas, 1993). Livestock genome mapping is a parallel process for producing comprehensive maps of the genomes of domestic animal species. In general, there are two basic types of gene maps.

- Joumal Paper No. J-17315 of the lowa Agriculture and Home Economics Experiment Station, Ames, Iowa. Project No. 3043. 
The genetic linkage map is a group of genes and markers that are linked together on a chromosome. These loci are separated by distances called centimorgans (cM), which represent the frequency of crossovers or recombination frequency. The smaller the distance between two loci, the more likely it is that the loci and their effects will be inherited together. In humans, the average map distance between loci is less than $1 \mathrm{cM}$ apart. In pigs, the genetic linkage maps are at an average of $5 \mathrm{cM}$ spacing of loci. The second type of genetic map is a physical or cytogenetic map which represents the physical location of a gene or marker on a chromosome based on the G-banding pattern of metaphase chromosomes. Physical maps are useful for establishing large regions of chromosomes that are syntenic between species, or in finding the location of an individual gene.

A more recent emphasis is to develop extensive comparative genome maps (O'Brien, 1993; O'Brien et al., 1993). A comparative map only includes genes, so that the location and the linkage and physical relationships of genes can be compared across species. 'Map rich' species like humans and mice are the foundation for comparative maps, as the information from these species is then used to infer the location of genes in 'map poor' species such as pigs. This is increasingly true since the human and mouse genomes have provided a growing number of expressed sequence tags (ESTs). ESTs are representative of genes and provide an additional resource for the identification of genes that could be mapped in livestock species. Combining the information from comparative, genetic linkage and the physical maps allows the geneticist to form a useful picture of the genetic composition of pigs.

\section{Status of the Pig Genome Maps}

For the significant effort required to generate genetic maps, scientists and administrators realized that a cooperative effort would be the most productive approach. The PiGMaP project (Archibald $e t$ al., 1995) was initiated in Europe and was funded by the European Economic Community. PiGMaP now involves 18 European laboratories and a total of seven other laboratories in the USA, Japan and Australia. In the USA, the USDA launched two efforts. The USDA-ARS directs a sizeable gene mapping project at the Meat Animal Research Center in Clay Center, Nebraska. Secondly, the USDACSRS sponsored National Animal Genome Research Program was developed in 1993 to provide a structure that would stimulate coordination and collaboration of gene mapping in livestock species, including pigs. Scientists from state and private universities and federal laboratories cooperatively created a Swine Genome Technical Committee with a coordinator. The US Pig Genome Coordinator activities, in concert with activities of the USDA-ARS and international gene mapping projects have allowed the pig gene maps to be produced quickly. In 1989, only 50 genes and markers were mapped in pigs, and many of these were isozyme or blood group markers. At present, nearly 1700 markers and genes have been mapped in pigs (Ellegren et al., 1994; Archibald et al., 1995; Rohrer et al., 1996), although not all have been published. The most extensive pig map has over 1100 loci (Rohrer et al., 1996), and consists mostly of anonymous markers. The new PiGMaP genetic linkage map will have over 650 loci on the map, including nearly 200 genes. Coverage for the different linkage maps varies, and while the average distance between markers is approximately $5 \mathrm{cM}$, some large gaps still remain. The physical genetic map (see Fig. 1 for example) in pigs currently consists of approximately 700 genes and markers in part resulting from some excellent resources such as somatic cell hybrids for physical mapping (Yerle et al., 1996). Despite these concerted efforts, the pig genome map still pales in comparison with the human and mouse maps and indicates the need for additional funding and effort. Over 20000 genes and markers have been mapped in humans and over 15000 in mice. As more genes are placed on the livestock comparative map, the human genome map will have increased use in the search for individual genes responsible for traits of economic interest.

\section{Early Approaches to Finding Genes Controlling ReproductiveTraits}

Quantitative trait loci, or QTL, are single genes that have a 'large' effect on a given trait and are also often called Economic Trait Loci (ETL). A QTL is likely to have been identified when there is a mean 


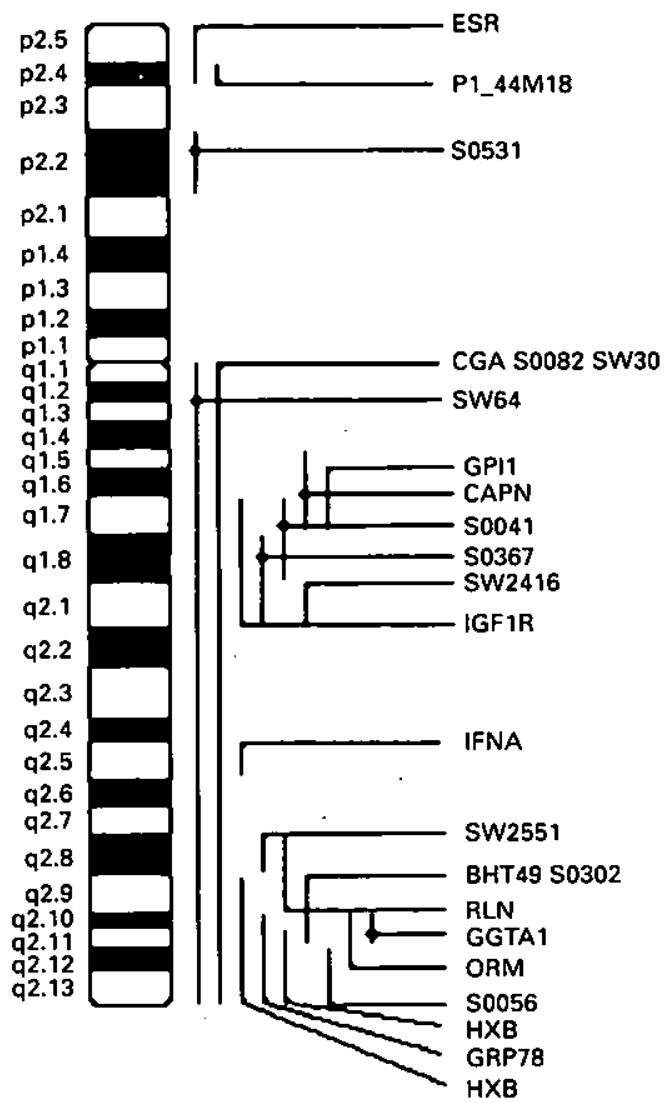

Fig. 1. The cytogenetic map for chromosome 1 in the pig. The map contains several genes including the oestrogen receptor (ESR) and several microsatellite markers. See http://www.iastate.edu/ -pigmap.

difference in trait measurements between alleles of a gene or marker. The researcher must be able to follow the pattern of segregation of the alleles of the gene with the performance differences of the traits of interest. This requires the use of resource populations or families that usually comprise two or three generations. There are several resource families using diverse breed crosses in the world, as well as additional resource families from crosses of specialized lines. Resource family material is the foundation of genetic QTL identification and mapping. While there are several resource families for growth and production traits, reproduction trait family resources remain limited.

Two primary strategies used to detect QTL or major genes include the use of anonymous markers such as microsatellites and the use of candidate genes. The first approach uses microsatellites that are well spaced across the genome to genotype all the animals in the resource families. Then sophisticated statistical methods are used to determine the closest markers to a QTL affecting a given trait. This is called a genomic scan and can be an effective way to identify chromosomal regions that may contain a QTL:- However, the size of such experiments must be considerable to detect QTL of moderate or small effects. Large-scale genotyping is becoming increasingly cost-efficient, but the cost of gathering phenotypic data on many individuals is significant.

An alternate strategy is to investigate a specific candidate gene as a potential QTL based upon its chromosomal location or its direct or indirect involvement in reproductive trait physiology. Once a candidate gene is identified and mapped in pigs, genotypes are obtained for individuals within a 
resource population. These genotypes are analysed with phenotypic data to identify possible associations between the gene and the trait. This approach relies considerably on available gene sequence information and genetic comparative maps from other species.

\section{Early Results}

Early genetic investigations into reproductive traits centered on the identification of blood groups and protein polymorphisms and primarily their association with litter size. The first evidence of such associations was obtained by Jensen et al. (1968) and Rasmusen and Hagen (1973), who reported an association between the $H$ locus on pig chromosome 6 and litter size with an unfavourable effect of the Ha allele. Kristjansson (1964) and Imlah (1970) reported an apparent effect of alleles at the transferrin locus (pig chromosome 13) on pig fertility and prolificacy but this was not confirmed by other investigators (Jensen et al., 1968; Huang and Rasmusen, 1982). Several other associations between blood group loci and reproductive traits have led to contradictory results (for example Kennedy et al., 1973; Rasmusen 1975; Renard et al., 1988). The most widely studied gene has been the ryanodyne receptor or halothane sensitivity (Hal) locus. Although best known for its major effects on carcass and meat quality traits in pigs, various and inconsistent effects of the Hal locus on male and female reproductive performance have been reported (Carden et al., 1985; Lampo et al., 1985).

During the 1980s, there was considerable investigation of the role of the major histocompatibility complex (MHC) called the swine leukocyte antigen (SLA) complex on male and female reproductive traits (reviewed in Warner and Rothschild, 1991). The swine MHC is a large group of genes on pig chromosome 7. Swine MHC effects on male testicular traits, with 1.5-5\% of the phenotypic variation in male testicular size and hormone differences explained, have been reported (Rothschild et al., 1986a). In females, the MHC also appears to be associated with several traits including ovulation rate (Rothschild et al., 1984; Conley et al., 1988), litter size, number of pigs born alive and number weaned (reviewed in Vaiman et al., 1988; Warner and Rothschild, 1993). There is evidence to suggest that embryo homozygosity within the MHC may be a disadvantage (Vaiman et al., 1988). Results in NII miniature pigs have also indicated the presence of an MHC gene affecting embryo development and its relationship to litter size (Ford et al., 1988). Other reports (Rothschild et al., 1986b; Vaiman et al., 1988; Warner and Rothschild, 1991) have demonstrated an association of MHC with birth and weaning weight. Whether these effects are the direct result of genes within the MHC or are due to linkage with other genes outside the complex is unknown. This question can only be resolved by further cloning and identification of individual genes on pig chromosome 7.

Recent discoveries, like the Booroola fecundity gene ( $\mathrm{FEC}^{\mathrm{B}}$ ) locus in sheep, have encouraged researchers to search for individual genes influencing reproductive traits in pigs. Initial interest included the investigation of the prolificacy of some breeds of pig, like the Chinese Meishan. In 1991, Rothschild and colleagues began a candidate gene investigation of the role of the oestrogen receptor (ESR) gene in controlling litter size. Given that oestrogen is central to all reproductive processes, it was assumed that ESR would be an important candidate gene. Early results demonstrated that one ESR allele, found first in the Meishan and later in the Large White breed, was associated with improved litter size in a Meishan $\times$ Large White composite line (Rothschild et al., 1994). An example of the ESR test is given (Fig. 2). More recent results (Rothschild et al., 1995; Rothschild et al., 1996; Short et al., 1997) in Chinese crosses show first parity differences between ESR homozygotes to be nearly 2.3 pigs per litter or an additive effect of an increase of 1.15 pigs per litter for each copy of the $B$ allele. In subsequent litters, the effect of the $B$ allele is about 0.5 pigs per litter and appears to act in a dominant manner (Table 1). The B allele is also segregating in several Large White populations (Rothschild et al., 1995; Legault et al., 1996; Rothschild et al., 1996; Short et al., 1997b), but the effect of the $B$ allele seems to differ between populations. In the largest study involving four commercial lines (Short et al., 1997b) differences were additive for the B allele of about 0.42 pigs per litter or a difference of 0.84 pigs per litter between the AA and BB homozygotes (Table 1). The effect is only slightly smaller in later parities when the $B$ allele shows more of a dominant effect than an additive 


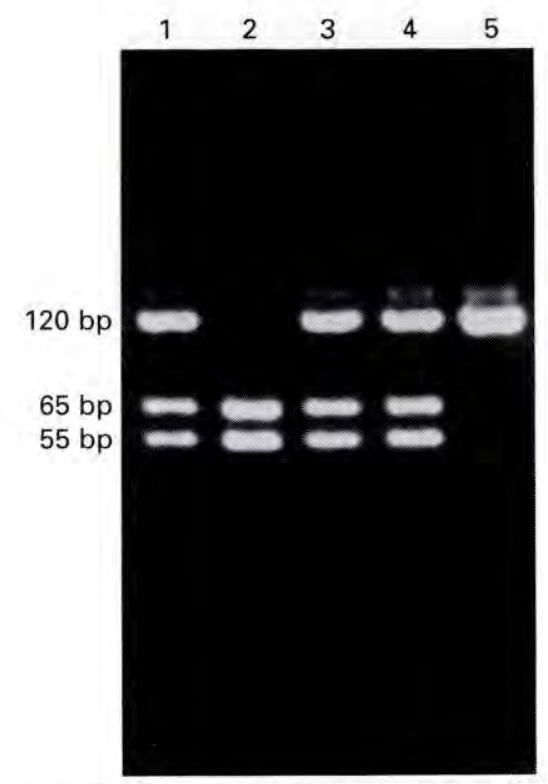

Fig. 2. The PCR-RFLP test for the oestrogen receptor polymorphism. Lane 2 contains a sample from a homozygous animal for the favourable $\mathrm{B}$ allele. Lane 5 contains a sample from an animal homozygous for the A allele and lanes 1, 3 and 4 contain samples from heterozygous animals. Reproduced with permission from the Journal of Animal Science.

effect. Line differences may either indicate that the ESR locus is only a linked marker or that differences in the genetic background have an impact on the expression of the ESR gene. Investigations are continuing to uncover the underlying mechanism of the favourable ESR allele.

It has been suggested that a statistical approach such as segregation analysis should precede molecular approaches to search for a major gene. This approach can be used to identify animals that are expected to carry different alleles for a gene, making a good starting point for a genomic scan. Janss et al. (1997) investigated the presence of major genes for litter size in an $F_{1}$ and $F_{2}$ Meishan and Western pig cross-population. A dominant gene was identified which resulted in a difference of five to six piglets between homozygotes. No significant effect was found in second parity litters. In the experiment, young sows were mated at a fixed age such that variation in the onset of puberty could affect first parity litter size. Therefore, it cannot be excluded that the major gene identified is partly related to the onset of puberty.

Genomic scans for reproductive traits have been limited. Using a cross between Meishan and Large White breeds, Wilkie et al. (1996) reported marker gene associations with number of pigs born per litter on a region of chromosome 6 . Regions of chromosomes 4 and 7 were associated with the number of stillbirths. An association between the microsatellite marker SW444 region on chromosome 8 and ovulation rate and uterine length was also reported (Wilkie et al., 1996). A second group has also identified an association between microsatellite markers (S0017, S0086) in this region of chromosome 8 in a similar synthetic population (G. Plastow, personal communication). In another study, Rathje et al. (1996) found a QTL for ovulation rate on pig chromosome 8 in a cross between a line selected for ovulation rate and a control line. A large study involving commercial pigs also suggests that this second chromosome 8 may contain a QTL with a major effect for litter size (Short 
Table 1. Effects of oestrogen receptor (ESR) genotype on total number born (TNB) and number born alive (NBA) of Meishan synthetic and Large White lines

\begin{tabular}{|c|c|c|c|c|c|c|}
\hline \multirow[b]{3}{*}{ ESR genotype } & \multicolumn{6}{|c|}{ Meishan synthetics } \\
\hline & \multicolumn{3}{|c|}{ First parities } & \multicolumn{3}{|c|}{ All parities } \\
\hline & TNB & NBA & $\mathrm{N}$ & TNB & NBA & $\mathrm{N}$ \\
\hline AA & $10.1^{\mathrm{a}}$ & $9.1^{\mathrm{a}}$ & 62 & $11.0^{\mathrm{a}}$ & $10.2^{\mathrm{a}}$ & 98 \\
\hline $\mathrm{AB}$ & $11.4^{\mathrm{b}}$ & $10.5^{\mathrm{b}}$ & 73 & $12.4^{\mathrm{b}}$ & $11.5^{\mathrm{b}}$ & 125 \\
\hline \multirow[t]{3}{*}{$\mathrm{BB}$} & $12.4^{b}$ & $11.4^{\mathrm{b}}$ & 26 & $12.5^{\mathrm{b}}$ & $11.7^{\mathrm{b}}$ & 53 \\
\hline & \multicolumn{6}{|c|}{ Large White lines } \\
\hline & \multicolumn{3}{|c|}{ First parities } & \multicolumn{3}{|c|}{ Later parities } \\
\hline ESR genotype & TNB & NBA & $\mathrm{N}$ & TNB & NBA & $\mathrm{N}$ \\
\hline $\mathrm{AA}$ & $10.14^{\mathrm{a}}$ & $9.42^{\mathrm{a}}$ & & 11.36 & $10.03^{\mathrm{a}}$ & \\
\hline $\mathrm{AB}$ & $10.59^{b}$ & $9.87^{\mathrm{b}}$ & & $11.86^{\mathrm{b}}$ & $10.54^{b}$ & \\
\hline BB & $10.97^{c}$ & $10.22^{c}$ & & $12.04^{\mathrm{b}}$ & $10.71^{b}$ & \\
\hline
\end{tabular}

$a, b, c$ Means in the same column with different superscripts are significantly different $(P<0.01)$.

Data from Rothschild et al. (1996) and Short et al. (1997).

et al., 1997a). This part of chromosome 8 is syntenic with sheep chromosome 6 where FEC ${ }^{B}$ is located. Taken together, the results of these studies strongly suggest that a region or regions on chromosome 8 influence litter size, possibly through ovulation rate.

Recently, studies in our laboratory have begun to investigate several candidate genes for litter size. These genes are of interest because of their role in reproductive trait physiology and include retinoic acid receptor gamma (RARG), retinol binding protein 4 (RBP4), melatonin receptor $1 \mathrm{~A}$ (MTNR1A), prolactin (PRL), prolactin receptor (PRLR) and leptin receptor (LEPR).

Two of these genes, retinoic acid receptor-gamma (RARG) and retinol-binding protein 4 (RBP4), are expressed during rapid trophoblast elongation, a critical time of pregnancy in pigs. These genes were mapped by linkage analysis to pig chromosomes 5 and 14, respectively. The allele frequencies of the RBP4 gene (Messer et al., 1996a) and RARG gene (Messer et al., 1996b), although based upon a small representative sample of several domestic breeds of pig, may indicate a higher allele frequency in the maternal lines which may be due in part to selection for litter size in these breeds. Two French Large White lines were genotyped at these loci to investigate further possible effects of these genes. The first line consisted of French Hyperprolific (LWH) pigs (32 sows with 216 litter records). The second line consisted of French control (LW) pigs ( 27 sows with 242 litter records). The average additive effects of the RARG gene, estimated as the linear regression of litter size on genotype, was $0.21 \pm 0.30$ pigs per litter increase in LWH and $0.14 \pm 0.38$ pigs per litter increase in LW. The RBP4 gene had an additive effect for litter size of $0.52 \pm 0.30$ pigs per litter in $\mathrm{LWH}$ and $0.45 \pm 0.43$ in LW. The allelic substitution effect for litter size ranges from 5 to $17 \%$ of the phenotypic standard deviation (Messer et al., 1996c). These initial data suggest that alleles of RARG and RBP4 may account for increased litter size in pigs.

The French lines were also genotyped at the MTNR1A locus. Melatonin is a pineal gland hormone that is involved in circadian rhythm entrainment and seasonal breeding in some livestock, and exerts its effects by binding to receptors located in the brain. The frequencies of the $4.3 \mathrm{~kb}$ and $3.9 \mathrm{~kb}$ alleles were 0.23 and 0.77 in the hyperprolific line, and 0.04 and 0.96 in the control line (Messer, 1996). The differences in gene frequency at this locus between lines was strikingly different from those observed with the RBP4 and RARG genes. The $3.9 \mathrm{~kb}$ allele was also observed at high frequency in the Meishan, Wild Boar, Yorkshire and Large White breeds of pig (Messer et al., 1997) and suggests that an allele of MTNR1A may play a role in increased litter size. The differences in frequency might also be explained by factors such as breed differences, founder effects or genetic drift. Further investigation in large populations with several litter records is necessary to estimate better the possible effect of MTNR1A alleles on increased litter size. 
Prolactin is an anterior pituitary peptide hormone involved in many different endocrine activities and is essential for reproductive success. The mapping of prolactin on pig chromosome 7 has been recently refined by linkage and physical mapping (Vincent et al., 1996). The polymorphism used for the genetic linkage mapping was also used to screen unrelated animals of seven different breeds. Maternal breeds such as Meishan, Large White and Chester White contained genotypes not found in the paternal breeds tested. This marker is currently being investigated for associations with litter size in a crossbred population.

The prolactin receptor (PRLR) has been identified in various tissues including mammary gland, corpus luteum and uterus (Kelly $e t$ al., 1991) and is considered a litter size candidate gene because of its integral role in the prolactin pathway. A polymorphism was identified and used to linkage map PRLR to pig chromosome 16 . Initial screening of a commercial line indicated that the A allele had a favourable effect on litter size; AA females have litters of 0.66 pigs more per litter than do AB or $B B$ females (Vincent $e t$ al., in press). This marker is being used to screen various other commercial lines to confirm the early findings.

Another gene which may influence reproductive traits is the leptin receptor (LEPR). Leptin is a protein secreted by adipose tissue and is thought to signal satiety by binding to leptin receptors in the brain. Mice with mutations in LEP (ob/ob) and LEPR $(\mathrm{db} / \mathrm{db})$ genes are infertile as well as obese. Treatment with leptin has been shown to stimulate the reproductive endocrine system in female and male ob/ob mice (Barash et al., 1996). A different isoform of the receptor than that found in the brain has been shown to be expressed in human ovary and prostate (Cioffi et al., 1996). LEPR has been physically (Ernst $e t$ al., 1997) and linkage mapped to pig chromosome 6 (Vincent and Rothschild, personal communication). Again, seven different breeds were genotyped using the LEPR polymorphism. There were no obvious indications of a maternal allele, but future work will consider possible links between obesity and reproduction.

Very large populations with several litter records are necessary in these studies for a more representative estimate across breeds and to allow for a better understanding of the size of the effects of reproduction genes. Considerable investment in resources is needed to accomplish the collection of both genotypes and phenotypic information. It will be interesting to determine how many of these new candidate effects are confirmed when the studies are completed.

\section{Beyond Candidate Genes and Initial Genome Scans}

As indicated in the previous section, both candidate gene investigations and genomic scans have found genes and regions of chromosomes that are worthy of further investigation. Finding the gene causing the desired effect in such regions is a complicated and difficult process. In many cases genome scans will find regions that are from $10-25 \mathrm{cM}$ in size. This region of $10-25 \times 10^{6}$ nucleotides could contain hundreds of genes and it is very difficult by linkage mapping approaches to determine which single gene is responsible for the effect. Efforts are needed to narrow the QTL to a 1-2 cM region, making a positional cloning approach more feasible.

When the QTL region has been narrowed to $20 \mathrm{cM}$ or less, the researcher may try to identify a positional candidate gene. The comparative gene map is a valuable resource to indicate candidate genes in the QTL region. If some of these genes have been mapped in other species or are known to cause similar phenotypes, these comparative positional candidates genes can be evaluated further. Candidate genes identified in other species must be genetically and physically mapped in pigs to ensure that their map position is closely linked to the QTL. Some positional candidate genes will be eliminated because they do not map to the region of interest in pigs. If the new candidate gene does map to the area of interest, further analysis can be attempted.

If, however, there are no obvious positional candidate genes, or those chosen do not prove to be the QTL, then additional genetic markers are needed to saturate the QTL region. There are several techniques for finding new genetic markers. Chromosomal flow sorting (Yerle et al., 1993) allows libraries of specific chromosomes to be constructed. The region can be narrowed further by microdissection of chromosomes which permits libraries consisting of unique chromosomal regions 
to be generated (Schmutz et al., 1994). Libraries can then be screened to find region-specific microsatellites. Another approach is to use amplified fragment length polymorphisms (AFLPs) to develop new anonymous polymorphic markers (Plastow, 1997). New markers must be mapped both genetically and physically. The development of radiation hybrid panels will allow high-resolution physical mapping of newly identified markers (Rexroad and Womack, 1997).

New markers that flank the QTL may then be used to identify yeast artificial chromosomes (YACs) which might contain the gene of interest or additional anonymous markers. YAC libraries consist of large genomic insert clones, which contain fragments of up to several hundred kilobases. These YACs could be used to screen smaller insert libraries to converge upon a more manageable fragment. The desired gene or region of the gene can then be identified by several techniques including exon trapping, cDNA selection and CpG island rescue (Valdes et al., 1994; Gardiner et al., 1995; Krizman, 1996).

All new genes that are identified in the QTL region by these approaches must be evaluated further to determine an association of the gene with trait differences. This might be accomplished by sequence analysis, the identification of restriction fragment length polymorphisms (RFLPs), or expression level variation. Finally, the gene effect should be validated in a variety of populations. All of these processes are laborious and expensive. Clearly excluding a gene is much easier than proving it is the QTL.

\section{Marker-Assisted Selection}

Once QTL or major genes are identified, their use in commercial situations is accomplished through marker assisted selection (MAS). MAS is best applied to traits of low heritability or traits measured in one sex. For these reasons, reproductive traits are often suggested as prime targets for MAS. Selection is the best approach when the gene or QTL is in well-established lines and breeds and the beneficial allele is at an intermediate gene frequency. Animals are simply selected to increase the gene frequency of the desired QTL or decrease the frequency of an undesirable gene. Another application is the introgression (repeated back crossing) of a QTL or major gene discovered in an exotic or uncommon breed into a preferred line. For example, both of these techniques have been used by the pig breeding company, PIC, to increase the frequency of the favourable ESR allele in their commercial pig stocks. The use of MAS should only be done in concert with selection based on standard performance measures and care should be taken that antagonistic pleiotropic effects do not exist (see Rothschild et al., 1996; Short et al., 1997b). Another method for using QTL or a major gene would be the introduction of the gene into a new population using gene transfer (transgenics). However, this approach has not been undertaken for reproductive traits in pigs. Further technology will probably be developed before this approach can be used. Consumer concerns about transgenic pigs may prevent a widespread acceptance of such an approach in commercial pigs.

\section{Conclusion}

It is now possible to localize QTL and genes controlling complex traits, but additional developments are needed before the potential can be realised and the genetics of complex traits in pigs are more effectively dissected. Improved reproduction records for large resource families are necessary to map genes with moderate to small effects as are efficient genotyping methods to make these projects more economically feasible. Current maps, with markers at 3-5 cM spacing will need to be saturated with markers at intervals of 1-2 cM. These saturated maps are crucial for the eventual cloning of the genes affecting reproductive traits. Advanced comparative genetic maps will certainly aid in the process of finding positional candidate genes. An improved understanding of complex physiological traits is also imperative for identifying candidate genes. The discovery of useful major genes and QTL should be valuable for pig producers. It is likely that several gene tests will be available in the future, aiding in the development of specialized lines and new genetic packages for 
the producer. The ultimate beneficiary of these new developments will be the consumer who can purchase improved livestock products at a reasonable price.

The authors wish to express their appreciation to G. Plastow for his comments and suggestions. Contributions of their colleagues at lowa State University, PiGMaP and NC-210 collaborators are appreciated. Financial support and technical assistance from PIC, Dalgety FTC, and the Biotechnology Research Development Corporation, for several research projects and the USDA-CSREES for Pig Genome Coordination is also appreciated.

\section{References}

Archibald A, Brown J, Couperwhite S, McQueen H, Nicholson D, Haley C, Couppieters W, van de Weghe A, Stratil A, Wintero A, Fredholm M, Larson N, Nielsen V, Milan D, Woloszyn N, Robic A, Dalens M, Riquet J, Gellin J, Caritez J-C, Hue D, Burgaud G, Ollivier L, Bidanel J-P, Vaiman M, Renard C, Geldermann H, Davoli R, Ruyter D, Verstege E, Groenen M, Davies W, Hoyheim B, Keiserud A, Andersson L, Ellegren H, Johansson M, Marklund L, Miller R, Dear D, Signer E, Jeffreys A, Moran C, Le Tissier P, Muladno, Rothschild M, Tuggle C, Vaske D, Helm J, Liu H-C, Rahman A, Yu T-P, Larson RG and Schmitz C (1995) The PiCMaP consortium linkage map of the pig (Sus scrofa). Mammalian Genome 6 157-175

Barash I, Clement C, Weigle D, Hongping R, Kabigting E, Kuijper J, Clifton D and Steiner R (1996) Leptin is a metabolic signal to the reproductive system Endocrinology 137 3144-3147

Carden AE, Hill WG and Webb AJ (1985) The effects of halothane susceptibility on some economically important traits in pigs Animal Production 40 351-358

Cioffi J, Shafer A, Zupancic T, Smith-Gbur J, Mikhail A, Platika D and Snodgrass H (1996) Novel B219/OB receptor isoforms: possible role of leptin in hematopoiesis and reproduction Nature Medicine 2 585-589

Collins F and Galas D (1993) A new five-year plan for the U.S. human genome project Science 262 43-46

Conley A J, Jung YC, Schwartz NK, Warner CM, Rothschild MF and Ford SP (1988) Influence of SLA haplotype on ovulation rate and litter size in miniature pigs Journal of Reproduction and Fertility 22 595-601

Ellegren H, Chowdhary BP, Johansson M, Marklund L, Fredholm $M$, Gustavsson I and Andersson L (1994) A primary linkage map of the porcine genome reveals a low rate of genetic recombination Genetics 137 1089-1100

Ernst C, Kapke P, and Rothschild MF (1997) The leptin receptor gene (LEPR) maps to porcine chromosome 6 Mammalian Genome 8226

Ford, SP, Schwartz NK, Rothschild MF, Conley AJ and Wamer CM (1988) Influence of SLA haplotype on preimplantation embryonic growth rate in miniature swine Joumal of Reproduction and Fertility 84 99-104

Gardiner K, Ichikawa H, Ohki M, Patterson D and Cheng JF (1995) Localization of CDNAs to a region poorly represented in the CEPH chromosome 21 YAC contig: candidate genes for genetic diseases mapped to 21q22.3 Genomics 30 562-570

Huang MY and Rasmusen BA (1982) Parental transferrin types and litter size in pigs Journal of Animal Science 54 757-762

Imlah P (1970) Evidence for the Tf locus being associated with an early lethal factor in a strain of pig Animal Blood Croups and Biochemical Genetics 1 5-13

Janss LLG, van Arendonk JAM and Brascamp EW Segregation analysis for presence of major genes to affect growth, back fat and litter size in Dutch Meishan crossbreds Journal of Animal Science (in press)

Jensen EL, Smith C, Baker LN and Cox DF (1968) Quantitative studies on blood group and serum protein systems in pigs II - Effects on production and reproduction Journal of Animal Science 27 856-862

Kelly P, Djiane J, Postel-Vinay M, and Edery M (1991) The prolactin/growth hormone receptor family Endocrine Reviews 12 235-251

Kennedy BW, Moxley JE and Saison R (1973) Some relationships between blood group factors and economic traits in swine Canadian Journal of Animal Science 53 389-397

Kristjansson FK (1964) Transferrin types and reproductive performance in the pig Journal of Reproduction and Fertitity 8 311-317

Krizman DB (1996) Gene identification by $3^{\prime}$ terminal exon trapping Genetic Engineering (NY) 18 49-56

Lampo P, Nauwynck $W$, Bouquet $Y$ and vand Zeveren A (1985) Effect of stress susceptibility on some reproductive traits in Belgian Landrace pigs Livestock Production Science 13 279-287

Legault C, Gruand J, Lebost J, Garreau H, Ollivier L, Messer LA and Rothschild MF (1996) Frequence et effect sur la prolificite du gene ESR dams deux lignees Large White en France Journees Recherche Porcine en France 28 9-14

Messer LA (1996) Mapping of candidate genes for litter size in the pig p 77 Masters Thesis. Iowa State University, Iowa

Messer L, Wang L, Yelich J, Pomp, D, Geisert RD and Rothschild MF (1996a) Linkage mapping of the retinol-binding protein 4 (RBP4) gene to porcine chromosome 14 Mammalian Genome 7396

Messer L, Wang L, Yelich J, Pomp D, Geisert RD and Rothschild MF (1996b) Linkage mapping of the retinoic acid receptorgamma (RARG) gene to porcine chromosome 5 Animal Genetics 27 175-177

Messer L, Wang L, Legault C and Rothschild MF (1996c) Mapping and investigation of candidate genes for litter size in French Large White pigs Animal Genetics 27 (Supplement 2) 114

Messer L, Wang L, Tuggle CK, Yerle M, Chardon P, Pomp D, Womack JE, Barendse W, Crawford AM, Notter DR and Rothschild MF (1997) Mapping of the melatonin receptor 1A (MTNR1A) gene in the pigs, sheep and cattle Mammalian Genome 8 368-370

O'Brien SJ (1993) Genetic Maps Sixth Edition, Book 4 Nonhuman Vertebrates Cold Spring Harbor Laboratory Press, New York

O'Brien SJ, Womack, JE, Lyons LA, Moore KJ and Jenkins NA (1993) Anchor reference loci for comparative genome mapping in mammals Nature Genetics 3 103-112

Plastow G (1997) Demonstration of AFLP and its application to animal genome mapping and farm animal selection 
(molecular breeding with AFLP) In Exantples of Denonstration Projects in the Life Sciences Programmes Eds A Hernero, $M$ Jarvenpaa and I Norstedt European Commission DGXII Science Research and Development, Brussels EUR 16981 (in press)

Rasmusen BA (1975) A and O blood types and reproduction in pigs Journal of Animal Science 41256 (Abstract)

Rasmusen BA and Hagen KL (1973) The H blood-group system and reproduction in pigs Journal of Animal Science 37 568-573

Rathje TA, Rohrer GA and Johnson RK (1996) Quantitative trait loci affecting reproductive traits in swine Joumal of Animal Science 74 (Supplement 1) 122 (Abstract)

Renard C, Bidanel JP, Palovics A, Vaiman M, Guérin G and Runavot JP (1988) Relations entre des marqueurs génétiques et les caractères de production Journées Recherche Porcine en France $20315-320$

Rexroad CE and Womack JE (1997) Use of a whole genome radiation hybrid cell panel in constructing a high density map of bovine chromosome 1 Proceedings of the Plant and Animal Genonie V, (Abstract) p 297

Rohrer GA, Leeson JA, Hu Z, Smith TP, Keele JW and Beattie CW (1996) A comprehensive map of the porcine genome Genome Research 6 371-391

Rothschild MF (1996) Genetics and reproduction in the pig Animal Reproduction Science 42 143-151

Rothschild MF, Zimmerman DR, Johnson RK, Venier $L$ and Wamer CM (1984) SLA haplotype differences in lines of pigs which differ in ovulation rate Animal Blood Groups and Biochemical Genetics 15 155-158

Rothschild MF, Renard Ch, Sellier P, Bonneau $M$ and Vaiman M, (1986a) Swine lymphocyte antigen (SLA) haplotype effects on male genital trait development and androsterone level. In Proceedings of the 3rd World Congress on Genetics Applied to Livestock Production 11 197-202. Eds GE Dickerson and RK Johnson, University of Nebraska, Lincoln

Rothschild MF, Renard Ch, Bolet G, Dando P and Vaiman M (1986b) Effect of swine lymphocyte antigen haplotypes on birth and weaning weights in pigs Animal Genetics 17 267-272

Rothschild MF, Jacobson C, Vaske DA, Tuggle CK, Short T, Sasaki S, Eckardt GR and McLaren DG (1994) A major gene for litter size in pigs In Proceeding of the 5th World Congress on Genetics Applied to Livestock Production 21 225-228 Eds C Smith, JS Gavora, B Benkel, J Chesnais, W Fairfull, JP Gibson BW Kennedy and EB Burnside. University of Guelph, Guelph

Rothschild MF, Vaske DA, Tuggle CK, Messer LA, McLaren DG, Short TH, Eckardt GR, Mileham AJ and Plastow GS, (1995) Estrogen receptor locus is a major gene for litter size in the pig. In Proceedings of the European Association of Animal Production Ed. JAM van Arendonk p 53. Wageningen Pers, Wageningen

Rothschild MF, Jacobson C, Vaske DA, Tuggle CK, Wang L, Short T, Eckardt GR, Sasaki S, Vincent A, McLaren DG, Southwood O, van der Steen H, Mileham A and Plastow G (1996) The estrogen receptor locus is associated with a major gene influencing litter size in pigs Proceedings of the National Academy of Sciences USA 93 201-205

Schmutz SM, Berryere TG, Moker JS, Thue TD and Winkelman DC (1994) Gene mapping from a bovine 1:29 DNA library prepared with chromosome microdissection Mammalian Genome 5 138-141

Short TH, Southwood OI, DeVries AG, McLaren DG, Evans GJ, Mileham Al, and Plastow G (1997) Evidence of a new genetic marker for litter size in pigs fournal of Anintal Science (in press)

Short TH, Rothschild MF, McLaren DG, Southwood OI, DeVries A, van der Steen H, Tuggle CK, Helm J, Vaske DA, Mileham AJ and Plastow GS (1997) The effect of the estrogen receptor locus on reproduction and production traits in four commercial lines of pigs Joumal Animal Science (in press)

Vaiman M, Renard Ch and Bourgeux N (1988) SLA, the major histocompatibility complex in swine: its influence on physiological and pathological traits. In The Molecular Biology of the Major Histocompatibility Complex of Domestic Animal Species pp 23-38 Eds C. Warner, M Rothschild and S. Lamont lowa State Press, Ames IA

Valdes JM, Tagle DA and Collins FS (1994) Island rescue PCR: a rapid and efficient method for isolating transcribed sequences from yeast artificial chromosomes and cosmids Proceedings of the National Academy of Sciences USA 91 $5377-5381$

Vincent A, Wang L and Rothschild M (1996) Placement of prolactin on pig chromosome 7 by linkage and physical mapping ISU 1996 Swine Research Reports Ed. P. Holden pp 60-61 lowa State University Press, Ames LA

Vincent AL, Short TH, Southwood OI, Plastow GS, Tuggle CK and Rothschild MF The prolactin receptor gene is associated with increased litter size in pigs Proceedings of the Sixth World Congress on Genetics Applied to Livestock Production (in press)

Warner CM and Rothschifd MF (1991) The swine major histocompatibility complex (SLA) in Immunogenetics of the MHC Ed. R Srivasava, pp 368-397 Verlag Chemie International Publications, New York

Wilkie PJ, Paszek AA, Flickinger GH, Rohrer GA, Alexander LJ, Beattie CW and Shook LB (1996) Scan of 8 poncine chromosomes for growth, carcass and reproductive traits two likely quantitative trait loci Animal Genetics 27 (Supplement 2) 117-118

Yerle M, Schmitz A, Milan D, Chaput B, Monteagudo L, Vaiman M, Grelat G, and Gellin J (1993) Accurate characterization of porcine bivariate flow karyotype by PCR and fluorescence in situ hybridization Genomics 16 97-103

Yerle M, Echard G, Robic A, Mairal A, Dubut-Fontana C, Riquet J, Pinton P, Milan D, Lahbib-Mansais Y and Gellin J (1996) A somatic cell hybrid panel for pig regional gene mapping characterized by molecular cytogenetics Cytogenetic and Cell Genetics 73 194-202 